\title{
Saving for retirement by the self-employed*
}

\author{
DAVID JOULFAIAN \\ US Department of the Treasury, USA \\ (e-mail: david.joulfaianetreasury.gov)
}

\begin{abstract}
When compared with wage earners, the self-employed are reported to have a lower take up rate of tax-favored retirement plans in the United States. Using panel data from federal income tax returns for the years 1999-2006, this paper explores the various factors that shape the observed pattern of contributions to such plans by the self-employed. Consistent with previous findings in the literature, contributions rise with income, tax rates, as well as savings in taxable accounts. More interestingly, the novel findings in this paper address the role that debt plays in shaping contributions. While housing and business-related debts are accorded similar tax treatment, the findings show that contributions decline with business debt whereas they rise with household debt.
\end{abstract}

JEL CODES: H24, J26, L26

Keywords: Tax-deferred retirement saving, borrowing, self-employment.

\section{Introduction}

Business owners in the United States may share the very same desire to save for retirement as wage earners whose tax favored saving behavior has been studied extensively. Yet, they may respond to savings tax incentives differently. Business owners are known not to have diversified portfolios (Hubbard and Gentry, 2004), with a strong desire to re-invest in the firm and its expansion. Furthermore, business owners may face liquidity constraints in financing investments (Evans and Jovanovic, 1989; Holtz Eakin et al., 1994). These constraints may temper contributions to tax-deferred retirement plans.

In addition, and by investing in their own firms, the self-employed may enjoy much of the same tax benefits generated from contributing to tax qualified retirement plans, other things equal. The appreciation in the value of the business is not taxed until its sale, and completely escapes income taxation if passed on to heirs. In contrast, distributions from retirement saving plans are taxable income to their heirs. In addition, businesses receive a preferential treatment under the estate tax, both in terms of valuation discounts and installment payments at preferential terms, unlike pension assets,

\footnotetext{
* This paper was benefited from the comments of two anonymous reviewers and Alain Jousten. The views expressed are those of the author and do not necessarily reflect those of the US Department of the Treasury.
} 
which are fully and immediately taxable. While these factors may explain the difference in the behavior of wage earners and the self-employed, they shed little light on the factors that shape the savings pattern of the latter.

Because contributions are made on a pre-tax basis, and also because the return on contributions is tax-deferred, tax qualified retirement plans are viewed as superior to saving in taxable accounts. An extensive body of the literature has explored this incentive effect of taxes on contributions by wage earners and the population at large. ${ }^{1}$ But the self-employed may very well behave differently than the population at large and wage earners in particular. As an example, and using administrative records for the USA, Joulfaian and Richardson (2001) find that some $60 \%$ of wage earners contribute, directly or through their employers, to qualified retirement plans. This fraction rises to over $95 \%$ for those with high wages. In contrast, the comparable figures for the same period, and using the same data source, suggest a much lower take up rate for the self-employed (Schedule $\mathrm{C}$ income tax filers); about one third contribute with take up rates peaking at $63 \%$ for the most profitable (Joulfaian, 2009). ${ }^{2}$

The tax treatment of retirement savings by the self-employed, and unincorporated businesses in general, has evolved over several decades. For many years only owners of incorporated businesses were able to make tax favored contributions to their' qualified' retirement plans. The corporation made tax deductible contributions on their behalf, which became taxable upon distribution. Proprietors and, otherwise unincorporated business owners, were not able to benefit from such treatment until 1962 when Keogh plans were introduced. Since then, other, albeit simpler and less generous, alternative arrangements also became available.

Notwithstanding the tax incentives introduced over the past 5 decades, few studies to date have explored the tax-favored retirement saving pattern of the self-employed in the USA. Similarly, few have exploited administrative records to examine their saving behavior. A rare example is Power and Rider (2002) who examine panel data made up of the income tax returns of Schedule $\mathrm{C}$ filers (proprietors) and study the pattern of the combined contributions to Keogh and individual retirement accounts (IRAs), including contributions to benefit their employees (reported on Schedule C), in response to changes in tax regimes.

In addition, how contributions to such plans are influenced by arbitrage opportunities in the form of debt financed contributions and other financial considerations have yet to be fully explored. Do business debts crowd out retirement contributions, or do they create arbitrage opportunities and stimulate the latter? Similarly, do the personal finances of the self-employed in the form of housing mortgages form tax arbitrage opportunities and stimulate contributions? ${ }^{3}$

1 See Feenberg and Skinner (1989), Gale and Scholz (1994), Poterba et al. (1995, 1996), Engen, et al. (1996), Hubbard and Skinner (1996), Gale (1999), Kusko et al. (1994), Benjamin (2003), Chetty et al. (2014), and Heim and Lurie (2012) in general.

2 Throughout this paper, the terms self-employed, business owner, and proprietor are employed interchangeably.

3 See Manchester and Poterba (1989) and Kotlikoff (1990). Engen et al. (1996) show that contributors have significantly more non-mortgage debt (other than business debt) than non-contributors. Joulfaian and Richardson (2001) show that participation in tax-deferred retirement plans by wage 
The primary contribution of this paper is that it explores the role of the finances of the self-employed, such as business debts and home mortgages, in shaping retirement contributions, controlling for taxes, and other factors typically considered in the literature. It considers retirement contributions and debts, related to both business and home mortgages, as alternative forms of entrepreneurial saving decisions.

Section 2 provides an overview of retirement plans in the USA and the rules and restrictions that apply. Section 3 motivates the contribution decision and describes the data. In order to explore the pattern and the various factors that may influence contributions to qualified retirement plans, this paper employs panel data of federal income tax returns of a sample of the self-employed for the years 1999-2006. These are non-farm proprietors who typically file Schedule C (Form 1040) of the income tax return, some of whom chose to contribute towards their own retirement saving plans. Empirical results are reported in Section 4. Not surprisingly, contributions rise with the size of business income. Also consistent with past findings, they also rise with tax rates, and capital income in the form of interest and dividend income representing financial wealth. More interestingly, however, contributions decline with business related interest expenses. In contrast, they rise with home mortgage interest expenses (reported on Schedule A), a finding that is in harmony with the findings in the literature on the general population (e.g., Amromin et al., 2007). Section 5 concludes.

\section{Tax-deferred contribution rules}

The self-employed may contribute to three types of tax-favored or qualified retirement plans. Under the first type, the Defined Contribution (DC) plan, the rules apply to the amount contributed during working years. Under the second, the Defined Benefit (DB) plan, the rules apply to the amount of benefits a plan may pay at retirement. And last, the self-employed may contribute to IRAs.

\subsection{Keogh plans}

Under DC plans, a small business owner may contribute to two types of plans. Under the first, a profit sharing plan, the owner may contribute to his account (as well as to his employees) amounts based on the profits of the firm. Under the second, a money purchase plan, the owner contributes a fraction of the pay of the employees irrespective of the firm's profits or losses.

The maximum contribution to DC plans is the lesser of two limits. The first limit is a dollar cap that was set at $\$ 30,000$ from 1983 through 2000 . This limit was raised in steps in 2001 ( $\$ 40,000$ in 2002 to $\$ 49,000$ in 2009). The second limit caps contributions (as of 1983) at 25\% of net earnings. Because the latter is defined net of contributions in profit sharing plans, i.e., net earnings less retirement

earners rise with mortgage interest expenses. The relationship between contributions and mortgage payments, and the tax arbitrage opportunities, is more rigorously explored in Amromin et al. (2007). 


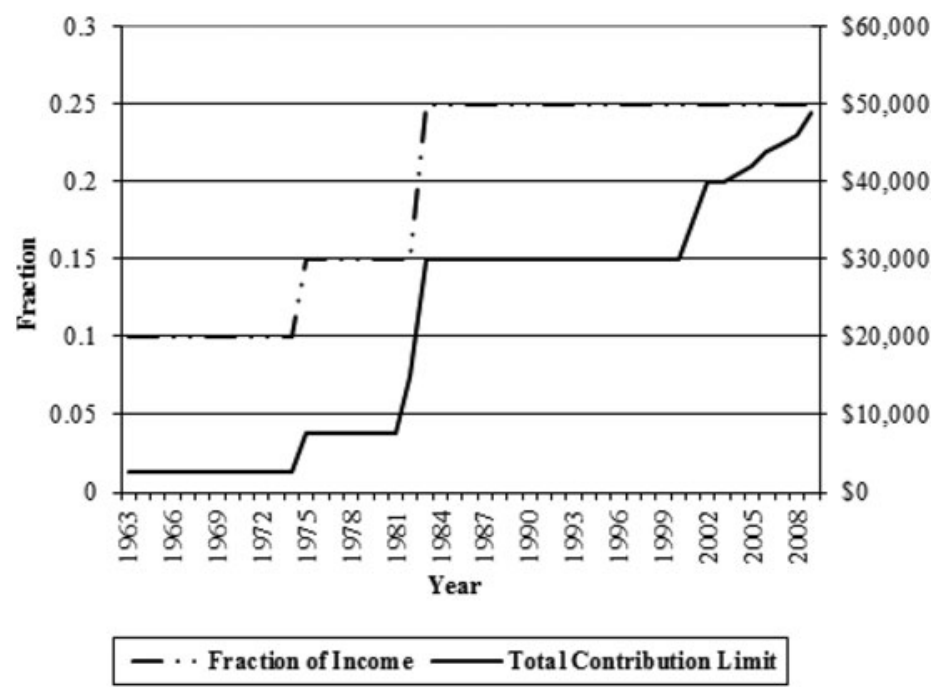

Figure 1. Contribution limits. Note: The contribution limit is the minimum of either the maximum statutory contribution amount and the fraction of income. The latter was raised to $100 \%$ of income up to $\$ 40,000$ for the self-employed in 2004.

contributions, the effective contribution rate is $20 \%$ only. ${ }^{4}$ Figure 1 traces the contribution limits. ${ }^{5}$

\subsection{DB Keogh plans}

The second variant of Keogh plans is a DB plan, which provides for a stream of benefits at retirement. This DB plan is different from the DC variant in that the rules and limits apply to annual benefits received after retirement and not directly to the annual contributions made during working years; the amount of annual contributions is determined so as to generate a preset stream of benefits. Under this type of plans, retirement benefits are set equal to a formula or actuarial determined fraction of annual earnings. Under current law, contributions to a Keogh DB plan are limited to amounts needed to generate annual pension distributions of the lesser of (1) $\$ 195,000$ for 2009 or (2) $100 \%$ of the average compensation for the three highest years. ${ }^{6}$ Figure 2 traces the benefit limits over the years.

Another key difference is that DB plans require continuous funding regardless of the profitability of the firm. However, actual contributions may not be equal to the formula

${ }^{4}$ With earnings $E$ and contributions $C$, the maximum contribution rate is determined as $C /(E-C)=0.25$, or $0.20 /(1-0.20)$ where $E=\$ 1$. Change introduced in 2004 allow for $100 \%$ deduction for the first $\$ 40,000$ of self-employment income.

5 Other small business retirement plans include Simple Employee Pensions (SEP) and Savings Incentive Match Plan for Employees (SIMPLE), which are easier to administer. However, and in general, defined contributions are coordinated so that no more than $\$ 46,000$ (in 2009) or $100 \%$ of compensation is contributed, including employer contributions.

${ }^{6}$ Depending on the age of the owner and the start date of the plan, annual contributions over a short number of years can be much larger than the stated annual benefit limit applied during retirement years. 


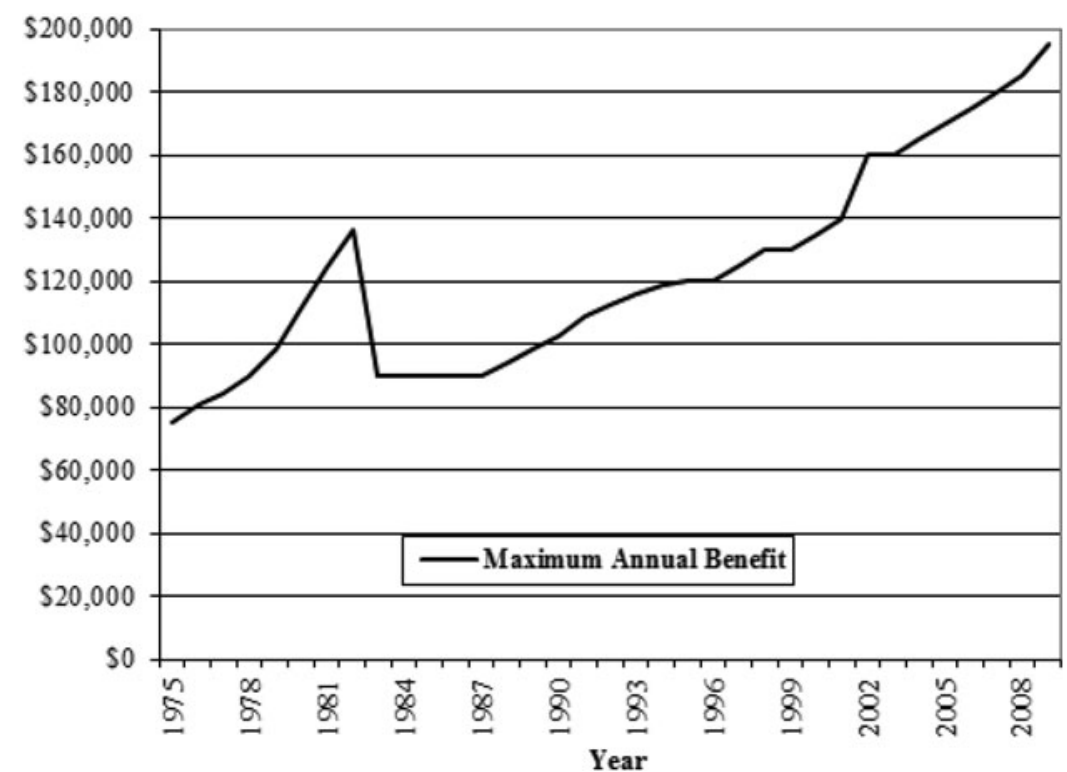

Figure 2. Benefit limits. Note: The benefit limit at retirement determines the contribution limit during working years.

set amount, reflecting on the appreciation in the value of assets held in retirement accounts. If the underlying assets, for instance, grow faster than the assumed rate of return, the account is then over funded, and smaller contributions need to be made.

\subsection{Individual retirement accounts}

Proprietors, as with wage earners, have the option to contribute to IRAs. These were introduced in 1974, their scope expanded in 1981, and then curtailed in 1986. However, these are less generous than Keogh plans, as they were capped at $\$ 2,000$ and phase out at low levels of income (as of 1987). Legislation enacted in 2001 expanded the contribution limit (\$5,000 in 2009). In addition, the Tax Relief Act of 1997 (TRA97) introduced Roth IRAs where contributions are not deductible but the return is exempt from tax.

\section{Modeling contributions}

\subsection{Motivation}

The role of tax incentives in stimulating retirement savings is well documented in the literature. Consider an individual who plans to set aside amount $y$ from income to save for retirement. When saved in an ordinary savings account, the amount of income set aside is reduced by taxes, and the individual is able to contribute only $(1-\tau) y$, where $\tau$ is the applicable income tax rate. The savings grow at the rate $r$, less taxes paid, and at retirement in $n$ years the accumulated savings net of taxes 
become:

$$
S_{1}=(1-\tau) y[1+r(1-\tau)]^{n}
$$

Alternatively, if the individual saves in a tax preferred account, then taxes are deferred until retirement and the accumulated savings grow to:

$$
S_{2}=y(1+r)^{n}(1-\tau) .
$$

The difference between (2) and (1) highlights the incentive effects of tax preferred accounts commonly illustrated in the literature, as $S_{2}>S_{1}$ for a given set of $y, r, \tau$, and $n .^{7}$

Notwithstanding the tax incentives, contributing to a tax preferred saving account may not be a simple exercise if the saver has an existing debt that can be paid down instead of contributing to a retirement plan, or she is contemplating to accumulate additional debt to fund contributions. By borrowing amount $B$, say in the form of a home equity loan, the individual may contribute to her retirement saving account amount $B /(1-\tau)$, reflecting on the tax savings from the income tax deferred. In $n$ years, the expected net of tax accumulated savings become:

$$
S_{3}=\frac{B}{1-\tau}(1+r)^{n}(1-\tau) \text {. }
$$

The borrowed funds, net of tax savings from deductability, and ignoring periodic payments of principle to simplify the discussion, also grow over time reflecting on the deductability of interest expenses. By year $n$ they become:

$$
S_{4}=B[1+i(1-\tau)]^{n},
$$

where $i$ is the interest rate charged by the lender. In order to maximize the gain from borrowing, $S_{3}-S_{4}$, the individual should borrow up to the point:

$$
(1+r)^{n}=[1+i(1-\tau)]^{n}
$$

or simply at:

$$
r=i(1-\tau)
$$

For $i=r$, the individual is always better off borrowing to fund retirement contributions. ${ }^{8}$ The tax arbitrage opportunity reflected in (5) and (6) is similar to that in Amromin et al. (2007).

The implicit assumption above is that the interest rate charged on debt is invariant to the amount borrowed. This is generally consistent with how mortgage rates are typically set in the USA with the underlying appraised property held as collateral. ${ }^{9}$ But in case of businesses, existing debt, or the size of borrowing in general, may very well

7 While this suggests that the saver is always better off saving in tax qualified retirement accounts, it does not account for the restrictions in accessing such accounts in pre-retirement years.

8 This is very much similar to borrowing and investing as a way to defer capital gains taxes in Stiglitz (1983).

9 Interest rates may generally increase with amount borrowed if the property is $80 \%$ or more leveraged, other things equal. 
shape the interest rate charged by the lender, and (4) above may be restated as:

$$
S_{5}=B[1+i(B)(1-\tau)]^{n},
$$

where $i(B)$ is now the interest rate charged such that $i_{B}>0$ and $i_{B B}>0$, reflecting bankruptcy risk, as well as cost of monitoring and information asymmetry between lenders and borrowers (e.g., Fazzari et al., 1988; Bernanke et al., 1999). The gain from borrowing to fund contributions becomes:

$$
S_{3}-S_{5}=B(1+r)^{n}-B[1+i(B)(1-\tau)]^{n} .
$$

Following first order conditions, this gain is maximized by borrowing up to the point:

$$
(1+r)^{n}=[1+i(B)(1-\tau)]^{n}+n i_{B} B(1-\tau)[1+i(B)(1-\tau)]^{n-1} .
$$

The gain from borrowing is smaller than that implied by (5) or (6), above, given the second term in (9). Funding retirement saving in the presence of business debt may not be as profitable when compared with the presence of housing debt as the interest rate $i$ rises with indebtedness given function $i(B)$ in the case of the former. But whether home mortgages and business debts have opposite effects on contributions, of course, is an empirical question.

\subsection{The data}

To explore the factors that shape retirement contributions by the self-employed, a panel data consisting of a random sample of US federal income tax returns is employed. This covers the years 1999-2006 from the continuing work history study, and represents a random sample of one in 1,000 of the universe of the tax filing population. ${ }^{10}$ From the income tax return (front page of Form 1040), we observe income and contributions to Keogh and IRA retirement plans. ${ }^{11}$ The latter contributions do not include contributions made on behalf of employees, which are reported separately as 'Pension and profit-sharing plans' business expenses on line 19 of Schedule C. And from Schedules A and C of the income tax returns we obtain information on the interest expenses on housing and business debts, respectively.

We restrict the sample to tax returns with positive net proprietorship income (computed before interest expenses) reported on Schedule C, as only profitable firms may make tax-deferred contributions as described above. As an example, contributions are typically limited to a fraction of positive income. In addition, only observations where the primary taxpayer is 21 years of age or older in 1999 and up to 70 years of age by 2006 (62 years of age in 1999) are considered here, before the forced distributions dictated by the tax code at age 70.5 years. Also excluded are individuals with income from businesses organized as partnership and $\mathrm{S}$ corporations since interest expenses are observed at the entity level and not the partner or shareholder level. This yields an unbalanced panel of 12,730 observations. Table 1 provides descriptive summary

10 Prior to 1998 , the CWHS sampling rate was one in 5,000, down from one in 1,000 .

11 As illustrated in Figure 1, the relevant contribution limits in 1999 were $\$ 30,000$ for DC Keogh, \$2000 for IRAs, $\$ 9,500$ for $401(\mathrm{k})$ and $403(\mathrm{~b})$ plans, and $\$ 7,500$ for 457 plans, with $\$ 120,000$ in annual benefits limit for DB Keogh. In 2006, these became \$44,000, \$5,000, \$15,000, \$15,000, and \$175,000, respectively. 
Table 1. Descriptive summary statistics

\begin{tabular}{|c|c|c|c|c|c|c|c|c|}
\hline \multirow[b]{2}{*}{ Variables } & \multicolumn{2}{|c|}{ All } & \multicolumn{2}{|c|}{ With contributions } & \multicolumn{2}{|c|}{ Without contributions } & \multirow[b]{2}{*}{ Mean Diff. } & \multirow[b]{2}{*}{$t$-test } \\
\hline & Mean & SE & Mean & SE & Mean & SE & & \\
\hline Contributions & 7,715 & 187 & 21,303 & 452 & 0 & 0 & & \\
\hline Contribution ratio $^{1}$ & 0.041 & 0.001 & 0.113 & 0.002 & 0 & 0 & & \\
\hline Business income & 153,893 & 3,319 & 302,685 & 7,799 & 69,419 & 2,246 & 233,266 & $28.7 * * *$ \\
\hline Interest + dividends $(t-1)$ & 5,095 & 238 & 10,095 & 523 & 2,257 & 219 & 7,838 & $13.8 * * *$ \\
\hline Home mortgage interest $(t-1)$ & 7,308 & 114 & 11,348 & 231 & 5,014 & 114 & 6,334 & $24.6 * * *$ \\
\hline Business interest expense $(t-1)$ & 4,669 & 199 & 5,770 & 331 & 4,045 & 249 & 1,725 & $4.2 * * *$ \\
\hline $1-\tau$ & 0.805 & 0.001 & 0.717 & 0.002 & 0.854 & 0.001 & -0.138 & $-67.6^{* * *}$ \\
\hline Married & 0.566 & 0.004 & 0.669 & 0.007 & 0.507 & 0.006 & 0.162 & $18.2 * * *$ \\
\hline Age & 49.8 & 0.0893 & 51.7 & 0.127 & 48.7 & 0.118 & 3.037 & $17.5^{* * *}$ \\
\hline Observations & 12,730 & & 4,610 & & 8,120 & & & \\
\hline
\end{tabular}

${ }^{1}$ Ratio of contributions to the sum of income and business interest expenses.

$* * *$ Significant at $1 \%$ level. 
statistics for select variables. The mean pre-interest self-employment income is $\$ 153,893$, with a standard error (SE) of $\$ 3,319$. This sample of the self-employed also received mean interest and dividend income of \$5,095 ( $\mathrm{SE}=238)$.

Turning to measures of debts, the self-employed also report average business interest expense of $\$ 4,669$ ( $\mathrm{SE}=199)$, with an average of $\$ 7,308(\mathrm{SE}=114)$ in home mortgage interest deductions, respectively. The mean (unconditional) contribution to tax-deferred retirement plans is $\$ 7,715(\mathrm{SE}=187)$, which represents an average saving rate of $4.1 \%$ ( $\mathrm{SE}=0.001)$ of business income. Overall, 4,610 observations, or $35 \%$ of the sample, made tax-deferred contributions. The mean age in the sample is 49.8 years $(\mathrm{SE}=0.089)$, with $57 \%$ of the observations married.

While the tax rate is not a key variable of interest as it has been extensively addressed in the literature, a word about its construction is warranted as there are a number of difficulties in computing the marginal tax rate that individuals face. Conceptually, the tax rate can be computed by adding $\$ 1$ (or some other increment) to contributions, and simulating the resulting tax liability as is the general practice. But because it is not always known whether the additional contribution would be deductible (e.g., DB type Keogh), the derived marginal tax rate will invariably be measured with error. As an alternative here, the tax rate is computed by assuming all individuals contribute from their income the sample mean contributions to income ratio, and the tax liability is computed over this range. While this approach may help reduce measurement errors and has the nice feature of being exogenous to contributions, the tax rate cannot be separately identified from income (Feenberg, 1987). To address this identification problem, an additional tax rate is computed by applying current year tax law to lagged income and the simulated tax rate is used as an instrument. The average net of tax rate is $0.805(\mathrm{SE}=0.001)$, for average tax rate of 0.195 .

\section{Results}

\subsection{Basic statistics}

As reported above, only $35 \%$ of the sample observations were contributed to a taxdeferred retirement plan. When compared with those not contributing or participating in a plan, and as revealed in columns 2 and 3 of Table 1, contributors seem to enjoy higher business incomes than non-contributors; mean of $\$ 302,685$ vs. 69,419 . They also seem to have greater financial wealth, with mean capital income (interest plus dividends) of $\$ 10,095$ compared with $\$ 2,257$ for non-contributors. Contributors are more likely to be married (67 vs. 51\%), and on average are about 3 years older (51.7 vs. 48.7 years). They also face higher tax rates; the mean net of tax rate $(1-\tau)$ for contributors is 0.72 compared with 0.85 for non-contributors.

Turning to the two measures of indebtedness, namely home mortgages and business debt our key variables of interest, contributors report much greater mortgage interest expenses than non-contributors; 11,348 vs. 5,014. This is in contrast to the smaller disparity in the mean amount of business interest expenses; 5,770 $(\mathrm{SE}=331)$ vs. 4,045 $(\mathrm{SE}=249)$. Those who contribute seem to carry greater home mortgages, but with 
a smaller difference in the case of business debt. Along with the attributes above, all of these difference are statistically significant.

To gain a greater perspective of the attributes of contributors and non-contributors, Table 2 expands on Table 1 by tabulating these attributes by the size of contributions made. Ten classes are considered ranging from zero to over $\$ 200,000$ in contributions. As we move from one class to another, we observe larger contributions to be generally associated with larger business income, greater financial resources (interest plus dividend income), higher tax rates (decline with net of tax rate), and older age. More to the point, they are also generally associated with larger home mortgage interest expenses. In contrast, no clear pattern is observed for business interest expenses.

For the largest contributors, those saving over $\$ 200,000$, smaller debts are observed but with much larger capital income observed. The latter, when capitalized, implies large financial wealth that can be used to fund contributions. ${ }^{12}$ This class of contributors is also generally older than the other reported classes.

\subsection{Multivariate estimates}

The basic tabulations above suggest that housing debt, when contrasted with business debt, plays a more important role in shaping contributions. In order to shed further light on the factors that shape contributions to tax-deferred retirement plans, multivariate estimates are prepared next. But to help set the stage for estimation, let us first consider a self-employed individual with earnings of say $\$ 200,000$ per year. She may contribute to an IRA account a maximum of $\$ 2,000$ (or $\$ 5,000$ depending on law and year). Alternatively, this proprietor may contribute instead a maximum of $\$ 30,000$ (or $\$ 44,000$, again depending on law and year) to a DC type Keogh plan. Under another option, much of the earnings could be contributed to a DB type Keogh plan. Because we are unable to distinguish between contributions to DC and DB type Keogh plans, and identify the various limits that may apply to contributions, modeling the retirement saving behavior of the self-employed is a difficult undertaking; we do observe contributions, but do not know precisely whether contribution limits are binding and which regime is in effect.

Given the uncertainty in identifying the binding statutory limits, and following the practice commonly employed in the literature, contributions are modeled with the various statutory upper limits ignored. More to the point, and to the extent that proprietors are able to contribute much of their income under DB plans, and free to choose any saving vehicle of their choice, no upper limit is imposed. ${ }^{13}$ Given the nature of the data on contributions (not every individual saves for retirement), they are truncated at low values; there is a minimum of zero in contributions. Labeled as $y$, this is modeled as:

$$
y^{*}=\beta x+\epsilon
$$

12 If lagged capital income were capitalized by applying an average 3-year Treasury note rate of 3.23 over the sample period percent and a dividend yield of $1.6 \%$, the grossed up value of the underlying financial assets would be $\$ 1.13$ million.

13 If we were to observe the type of a plan contributed to, then we would have to model the choice of a plan as well; DB vs. DC vs. IRA, and vs. a combination of plans. Alternative limits are considered below. 
Table 2. Distribution of contributions (C): mean values followed by $S E$

\begin{tabular}{|c|c|c|c|c|c|c|c|c|c|}
\hline $\mathrm{C}$ in $\$ 1,000 \mathrm{~s}$ & Obs. & $\mathrm{C}$ & $\mathrm{C} /$ Business income & Business Income & Capital income & Mortgage interest & Business interest & $1-\tau$ & Age \\
\hline \multirow[t]{2}{*}{ Zero } & 8,120 & 0 & 0 & 69,419 & 2,257 & 5,014 & 4,045 & 0.854 & 48.70 \\
\hline & & 0 & 0 & 2,246 & 219 & 114 & 249 & 0.001 & 0.12 \\
\hline \multirow[t]{2}{*}{$0<C \leqslant 5$} & 1,362 & 2,924 & 0.096 & 106,670 & 4,902 & 6,368 & 7,146 & 0.791 & 51.20 \\
\hline & & 34 & 0.004 & 5,142 & 342 & 271 & 673 & 0.003 & 0.25 \\
\hline \multirow[t]{2}{*}{$5<C \leqslant 10$} & 797 & 7,589 & 0.110 & 179,143 & 7,914 & 9,056 & 6,140 & 0.737 & 53.20 \\
\hline & & 50.8 & 0.006 & 8,225 & 731 & 441 & 672 & 0.003 & 0.31 \\
\hline \multirow[t]{2}{*}{$10<C \leqslant 20$} & 653 & 14,799 & 0.113 & 228,791 & 8,244 & 12,178 & 3,847 & 0.706 & 51.70 \\
\hline & & 117 & 0.003 & 10,785 & 828 & 595 & 426 & 0.003 & 0.35 \\
\hline \multirow[t]{2}{*}{$20<C \leqslant 30$} & 731 & 26,017 & 0.107 & 420,337 & 14,880 & 14,428 & 4,362 & 0.651 & 50.40 \\
\hline & & 112 & 0.003 & 19,988 & 2,452 & 617 & 437 & 0.002 & 0.31 \\
\hline \multirow{2}{*}{$30<C \leqslant 50$} & 860 & 39,590 & 0.114 & 591,278 & 16,079 & 16,452 & 5,669 & 0.660 & 51.60 \\
\hline & & 142 & 0.002 & 30,682 & 1,447 & 677 & 1,106 & 0.002 & 0.26 \\
\hline \multirow{2}{*}{$50<C \leqslant 75$} & 60 & 58,504 & 0.136 & 800,811 & 14,025 & 20,470 & 10,697 & 0.636 & 52.90 \\
\hline & & 769 & 0.016 & 96,542 & 2,444 & 2,998 & 4,382 & 0.005 & 0.78 \\
\hline \multirow[t]{2}{*}{$75<C \leqslant 100$} & 48 & 86,753 & 0.197 & 648,783 & 13,494 & 18,931 & 3,433 & 0.660 & 53.10 \\
\hline & & 1,166 & 0.023 & 53,495 & 2,490 & 2,805 & 1,249 & 0.009 & 0.80 \\
\hline \multirow[t]{2}{*}{$100<C \leqslant 200$} & 69 & 138,499 & 0.296 & 634,349 & 18,796 & 20,993 & 8,320 & 0.666 & 57.90 \\
\hline & & 3,407 & 0.016 & 65,622 & 3,313 & 2,989 & 2,622 & 0.007 & 0.72 \\
\hline \multirow[t]{2}{*}{ Over 200} & 30 & 273,790 & 0.471 & 639,631 & 22,525 & 6,374 & 478 & 0.664 & 57.50 \\
\hline & & 13,231 & 0.035 & 39,258 & 4,330 & 2,667 & 218 & 0.008 & 0.93 \\
\hline \multirow[t]{2}{*}{ All } & 12,730 & 7,715 & 0.041 & 153,893 & 5,095 & 7,308 & 4,669 & 0.805 & 49.80 \\
\hline & & 187 & 0.001 & 3,319 & 238 & 114 & 199 & 0.001 & 0.09 \\
\hline
\end{tabular}


where $y^{*}$ is a latent variable, and $x$ is a list of explanatory variables, including most notably personal debts outstanding. The observed amount contributed, $y$, the dependent variable, is defined as:

$$
\begin{aligned}
& y=0, \\
& y=y^{*}, \quad \text { if } y^{*}>0 .
\end{aligned}
$$

\subsubsection{Findings}

Given the lower zero limit, a set of Tobit equations for contributions are reported in Table 3, with robust standard errors (SE) reported in parentheses. In exploring the factors that shape how much of their income the self-employed contribute to retirement saving, we first begin with the two key measures related to individual debts: (a) business debt as measured by the firms reported interest expenses, and (b) housing debt as measured by home mortgage interest expenses of the self-employed, both lagged 1 year. Column (1) of Table 3, reports marginal effect estimates for the two measures of debts, with controls for budget constraints which include: (1) the size of pre-interest self-employment income as well as (2) the sum of interest and dividend income, as proxy for the size of financial wealth that can be used to fund contributions.

The estimated marginal effects of income and financial wealth are not surprising. Contributions to retirement plans rise with the size of self-employment income (business profits). The marginal effect is $0.0072(\mathrm{SE}=0.0002)$; doubling income leads to an increase in the contribution rate by 0.7 percentage points. As with the size of business income, contributions rise with the size of interest and dividend income from financial assets. The estimated marginal effect is $0.0073(\mathrm{SE}=0.0002)$; doubling of financial assets leads to an increase in the contribution rate by 0.7 percentage points. The latter may suggest some re-shuffling of portfolios between taxable and tax favored accounts, where those with large financial wealth may take advantage of the tax savings from deferrals. But this may also simply reflect an appetite to save in both taxable and tax favored accounts.

Turning to the key variables of interest, the marginal effect on housing debt, or mortgage interest payments, is positive with an estimated value of 0.00081 (SE = 0.00013). Evaluated at sample mean values, doubling of housing debt increases the contribution rate by 0.8 percentage points. In contrast, the estimated coefficient on business interest expenses is negative suggesting that the owners of firms that carry more debt contribute less. With an estimated value of $-0.00084(\mathrm{SE}=0.00014)$, and again evaluated at sample mean values, this suggests that doubling of business debt reduces the contribution rate by 0.8 percentage points.

The above estimates do not control for year fixed effects, which may capture macroeconomic and other factors influencing savings behavior. But these estimates change very little after controlling for year fixed effects as shown in column (2). The respective marginal effects on business debt and housing mortgages are virtually identical to those estimated earlier, and so are the estimated marginal effects on income and financial wealth. 
Table 3. Estimates of the share of business income contributed to retirement plans

\begin{tabular}{|c|c|c|c|c|c|}
\hline Variables & $\begin{array}{l}(1) \\
\text { Tobit }\end{array}$ & $\begin{array}{l}(2) \\
\text { Tobit }\end{array}$ & $\begin{array}{c}(3) \\
\text { Tobit }\end{array}$ & $\begin{array}{l}(4) \\
\text { Tobit }\end{array}$ & $\begin{array}{c}(5) \\
\text { Tobit IV }\end{array}$ \\
\hline $\begin{array}{l}\text { In Business interest expense } \\
(t-1)\end{array}$ & $\begin{array}{c}-0.000844 * * * \\
(0.000123)\end{array}$ & $\begin{array}{c}-0.000807 * * * \\
(0.000140)\end{array}$ & $\begin{array}{c}-0.000881 * * * \\
(0.000122)\end{array}$ & $\begin{array}{c}-0.000838 * * * \\
(0.000123)\end{array}$ & $\begin{array}{c}-0.000758 * * * \\
\quad(0.000130)\end{array}$ \\
\hline $\begin{array}{l}\text { ln Home mortgage interest } \\
(t-1)\end{array}$ & $\begin{array}{c}0.000813 * * * \\
(0.000129)\end{array}$ & $\begin{array}{c}0.000812 * * * \\
(0.000128)\end{array}$ & $\begin{array}{c}0.000888 * * * \\
(0.000127)\end{array}$ & $\begin{array}{c}0.000895 * * * \\
(0.000127)\end{array}$ & $\begin{array}{c}0.000924 * * * \\
(0.000129)\end{array}$ \\
\hline In Pre-interest business income & $\begin{array}{c}0.00717 * * * \\
(0.000507)\end{array}$ & $\begin{array}{c}0.00697 * * * \\
(0.000456)\end{array}$ & $\begin{array}{c}0.00748 * * * \\
(0.000507)\end{array}$ & $\begin{array}{c}0.00549 * * * \\
(0.000796)\end{array}$ & $\begin{array}{l}0.00252 * \\
(0.00130)\end{array}$ \\
\hline $\begin{array}{l}\text { In (Interest and dividends) } \\
(t-1)\end{array}$ & $\begin{array}{c}0.00728 * * * \\
(0.000361)\end{array}$ & $\begin{array}{c}0.00737 * * * \\
(0.000201)\end{array}$ & $\begin{array}{c}0.00677 * * * \\
(0.000350)\end{array}$ & $\begin{array}{c}0.00665 * * * \\
(0.000341)\end{array}$ & $\begin{array}{c}0.00648 * * * \\
(0.000234)\end{array}$ \\
\hline $\ln (1-\tau)$ & & & & $\begin{array}{c}-0.0243 * * * \\
(0.00661)\end{array}$ & $\begin{array}{c}-0.0610 * * * \\
(0.0129)\end{array}$ \\
\hline Married & & & $\begin{array}{c}-0.00386^{* * *} \\
(0.00120)\end{array}$ & $\begin{array}{c}-0.00355^{* * *} \\
(0.00121)\end{array}$ & $\begin{array}{c}-0.00303^{* *} \\
(0.00124)\end{array}$ \\
\hline $35 \leqslant$ Age $<45$ & & & $\begin{array}{c}0.0128 * * * \\
(0.00355)\end{array}$ & $\begin{array}{c}0.0127 * * * \\
(0.00355)\end{array}$ & $\begin{array}{c}0.0126 * * * \\
(0.00354)\end{array}$ \\
\hline $45 \leqslant$ Age $<55$ & & & $\begin{array}{c}0.0201 * * * \\
(0.00351)\end{array}$ & $\begin{array}{c}0.0201 * * * \\
(0.00351)\end{array}$ & $\begin{array}{c}0.0201 * * * \\
(0.00349)\end{array}$ \\
\hline $55 \leqslant$ Age $<65$ & & & $\begin{array}{c}0.0269 * * * \\
(0.00411)\end{array}$ & $\begin{array}{c}0.0265 * * * \\
(0.00410)\end{array}$ & $\begin{array}{c}0.0260 * * * \\
(0.00401)\end{array}$ \\
\hline Age $\geqslant 65$ & & & $\begin{array}{c}0.0362 * * * \\
(0.00649)\end{array}$ & $\begin{array}{c}0.0341 * * * \\
(0.00637)\end{array}$ & $\begin{array}{c}0.0311 * * * \\
(0.00625)\end{array}$ \\
\hline Year fixed effects & No & Yes & Yes & Yes & Yes \\
\hline Observations & 12,730 & 12,730 & 12,730 & 12,730 & 12,730 \\
\hline Positive observations & 4,610 & 4,610 & 4,610 & 4,610 & 4,610 \\
\hline
\end{tabular}

Robust SE in parentheses.

$* * * \mathrm{p}<0.01,{ }^{* *} \mathrm{p}<0.05,{ }^{*} \mathrm{p}<0.1$.

Note: Marginal Effect estimates. Dependent variable is the ratio of contributions to pre-interest business income. Column (5) excludes married individuals. 
Even after controlling for household demographics, such as marital status and age, the findings above do not materially change; they are slightly larger in absolute value. Married households seem to contribute a smaller share of their self-employment income, about 0.4 percentage points smaller $(\mathrm{SE}=0.0012)$ then their single counterparts. The contribution rate rises with age, and peaks for those age 65 through 70 .

Given the extensive coverage in the literature, the tax rate is not a key variable of interest. But because of the critical role it plays in shaping incentives for contributions, its omission may bias the estimates. Column (4) adds the net of the marginal tax rate. The estimated marginal effect enters with the expected negative sign, positive with respect to the tax rate. Its inclusion, however, has little effect on the estimates for the remaining regressors, except for that of income which is now smaller.

Because the effects of the net of tax rate cannot be separately identified from those of income, using the instrumented tax rate, Tobit IV estimates are provided in column (5) of Table $3 .{ }^{14}$ As discussed earlier, the tax rate instrument is constructed using current year tax law applied to lagged income, with first stage estimates reported in Table $4 .{ }^{15}$ The estimated marginal effect of the net of tax rate is now -0.06 (se = $0.013)$, much larger in absolute value than the earlier estimate reported in column (4) of Table 3 with a concomitant reduction in the estimated marginal effect of income. An increase in tax rates by 10 percentage points, or roughly $50 \%$ of the sample mean, leads to 2.4 percentage point increase in the contribution rate all evaluated at sample means. The estimated marginal effects of the remaining variables change little, except for income, which becomes further smaller.

\subsubsection{Robustness tests}

For married couples, it is not always clear which spouse makes the borrowing and the retirement saving decisions, or whether the decision of the spouses are independent. In addition, the notion that households maximize a single utility function, or that their behavior is independent of who controls resources or earns the income, has been challenged in the literature (e.g., Lundberg and Pollak, 1996). As a robustness test, the estimates in column (5) of Table 3 are replicated for the sample of singles with married individuals excluded. ${ }^{16}$ The estimated marginal effects reported in column (1) of Table 5 are qualitatively similar to those reported earlier for the entire sample; an exception is the age profile where the contribution rate peaks by age 55-65. Housing and business debts continue to carry the same sign and significance, albeit with smaller estimated marginal effects.

To explore the sensitivity of estimates to the presence of DB plans where very large contributions can be made, as well as the sensitivity of the estimates to Tobit limit assumptions, column (2) of Table 5 reports estimates using observations where

14 The Wald test for exogeneity $\left(\chi^{2}\right)$ is 10.79 with $\mathrm{p}=0.001$, and the null hypothesis of no endogeneity is rejected.

15 The estimated coefficients in the first stage regression have the expected signs on income and deductible expenses. The tax rate rises with business and capital incomes, whereas it declines with the deduction of interest expenses. The coefficient on the net of tax rate instrument is 0.466 , with large $t$ and implied $F$ statistics given the SE of 0.007 .

16 For this sub-sample, the mean contribution rate is $0.038(\mathrm{SD}=0.086)$, compared with $0.041(\mathrm{SD}=0.093)$ for the entire sample. Single individuals include widowed and divorced individuals. 
Table 4. First stage estimates for Tobit IV in Table 3

\begin{tabular}{lc}
\hline \hline Variables & OLS \\
\hline $\ln \left(1-\tau_{\mathrm{i}}\right)$ & $0.4664643^{* * *}$ \\
& $(0.0070797)$ \\
$\ln$ business interest expense $(t-1)$ & $0.0013442^{* * *}$ \\
& $(0.0002001)$ \\
$\ln$ Home mortgage interest $(t-1)$ & $0.0008644^{* * *}$ \\
& $(0.0001802)$ \\
$\ln$ Pre-interest business income & $-0.047312^{* * *}$ \\
& $(0.000794)$ \\
$\ln$ (interest and dividends) $(t-1)$ & $-0.0016774^{* * *}$ \\
& $(0.0002657)$ \\
Married & $0.008431^{* * *}$ \\
$35 \leqslant$ Age $<45$ & $(0.0015884)$ \\
$45 \leqslant$ Age $<55$ & 0.0032411 \\
& $(0.0032259)$ \\
$55 \leqslant$ Age $<65$ & 0.0053211 \\
Age $\geqslant 65$ & $(0.0031783)$ \\
Observations & -0.0016833 \\
$R$ & $(0.0032968)$ \\
$F$ statistic for instrument & $-0.0284587^{* * *}$ \\
Anderson-Rubin statistics $\left(\chi^{2}\right)$ & $(0.0040637)$ \\
$\mathrm{p}$ value & 12,730 \\
\hline \hline
\end{tabular}

$* * * \mathrm{p}<0.01, * * \mathrm{p}<0.05, * \mathrm{p}<0.1$.

Note: $\tau_{i}$ is the tax rate instrument computed using lagged income and current law. Year fixed effects not reported.

reported contributions do not exceed the limit for DC plans, which ranged from $\$ 30,000$ in 1999 to $\$ 44,000$ in 2006 , or up to $25 \%$ of income. Because contributions to DB and DC plans are not separately identified, this exclusion removes only large contributors and retains those who contributed to DB plans amounts up to the DC limits. ${ }^{17}$ As a consequence, the sample size is reduced to 12,207 observations, which excludes high income individuals making large contributions. The reported estimates are fairly similar to those reported earlier for the two debt measures. In contrast, the estimated marginal effect of business income is larger, and that of capital income, age, and the net of tax rate are smaller (in absolute value). ${ }^{18}$ The latter are

17 As an example, we cannot distinguish between DC and DB contributions in the amount of $\$ 44,000$ in 2006. Whereas a contribution of $\$ 100,000$ is most likely to a DB type plan.

18 The Tobit IV estimates with 0.25 upper limit are virtually identical to estimates obtained without using an upper limit. 
Table 5. Additional estimates of the share of business income contributed to retirement plans

\begin{tabular}{|c|c|c|c|c|c|c|}
\hline Variables & $\begin{array}{c}(1) \\
\text { Tobit IV }\end{array}$ & $\begin{array}{c}(2) \\
\text { Tobit IV }\end{array}$ & $\begin{array}{c}(3) \\
\text { Tobit IV }\end{array}$ & $\begin{array}{c}(4) \\
\text { Tobit IV }\end{array}$ & $\begin{array}{c}(5) \\
\text { Tobit IV }\end{array}$ & $\begin{array}{c}(6) \\
\text { Tobit IV }\end{array}$ \\
\hline ln Business interest expense $(t-1)$ & $\begin{array}{c}-0.000462^{* *} \\
(0.000184)\end{array}$ & $\begin{array}{c}-0.000715^{* * *} \\
\left(8.68 \times 10^{-5}\right)\end{array}$ & $\begin{array}{c}-0.00225^{* * *} * \\
(0.000183)\end{array}$ & $\begin{array}{c}-0.00190 * * * \\
(0.000581)\end{array}$ & $\begin{array}{c}-0.00122 * * * \\
(0.000179)\end{array}$ & $-(-)$ \\
\hline ln Home mortgage interest $(t-1)$ & $\begin{array}{l}0.000480 * * * \\
(0.000169)\end{array}$ & $\begin{array}{c}0.000731^{* * *} \\
\left(8.17 \times 10^{-5}\right)\end{array}$ & $\begin{array}{l}0.000873 * * * \\
(0.000187)\end{array}$ & $\begin{array}{l}0.000589 \\
(0.000484)\end{array}$ & $\begin{array}{l}0.000621^{* *} \\
(0.000256)\end{array}$ & $-(-)$ \\
\hline In Pre-interest business income & $\begin{array}{r}0.00413^{* *} \\
(0.00206)\end{array}$ & $\begin{array}{l}0.00536 * * * \\
(0.000677)\end{array}$ & $\begin{array}{r}-0.0381 * * * \\
(0.00225)\end{array}$ & $\begin{array}{l}0.00404 \\
(0.00305)\end{array}$ & $\begin{array}{l}0.00224 \\
(0.00215)\end{array}$ & $\begin{array}{l}0.00319 \\
(0.00382)\end{array}$ \\
\hline ln (Interest and dividends) $(t-1)$ & $\begin{array}{l}0.00498 * * * \\
(0.000303)\end{array}$ & $\begin{array}{l}0.00353 * * * \\
(0.000148)\end{array}$ & $\begin{array}{l}0.000990 * * \\
(0.000400)\end{array}$ & $\begin{array}{l}0.0105 * * * \\
(0.00130)\end{array}$ & $\begin{array}{l}0.00602 * * * \\
(0.000354)\end{array}$ & $-(-)$ \\
\hline $\ln (1-\tau)$ & $\begin{array}{r}-0.0425 * * \\
(0.0194)\end{array}$ & $\begin{array}{r}-0.0262 * * * \\
(0.00722)\end{array}$ & $\begin{array}{r}-0.0592 * * \\
(0.0247)\end{array}$ & $\begin{array}{r}-0.114 * * * \\
(0.0400)\end{array}$ & $\begin{array}{c}-0.0727 * * * \\
(0.0192)\end{array}$ & $\begin{array}{c}0.00227^{*} \\
(0.00117)\end{array}$ \\
\hline Married & & $\begin{array}{c}-0.00318^{* * *} \\
(0.000810)\end{array}$ & $\begin{array}{r}0.0134 * * * \\
(0.00197)\end{array}$ & $\begin{array}{r}-0.00413 \\
(0.00375)\end{array}$ & $\begin{array}{c}-0.00539 * * * \\
(0.00172)\end{array}$ & $\begin{array}{c}-0.000959 * \\
(0.000521)\end{array}$ \\
\hline $35 \leqslant$ Age $<45$ & $\begin{array}{r}0.00896^{* *} \\
(0.00369)\end{array}$ & $\begin{array}{c}0.00786 * * * \\
(0.00230)\end{array}$ & $\begin{array}{r}0.0152 * * * \\
(0.00540)\end{array}$ & $\begin{array}{l}0.0101 \\
(0.0114)\end{array}$ & $\begin{array}{l}0.0141 * * * \\
(0.00548)\end{array}$ & $\begin{array}{c}0.00129 \\
(0.00106)\end{array}$ \\
\hline $45 \leqslant$ Age $<55$ & $\begin{array}{r}0.0140 * * * \\
(0.00363)\end{array}$ & $\begin{array}{r}0.0123 * * * \\
(0.00226)\end{array}$ & $\begin{array}{r}0.0143 * * * \\
(0.00524)\end{array}$ & $\begin{array}{r}0.0255^{* *} \\
(0.0113)\end{array}$ & $\begin{array}{l}0.0214 * * * \\
(0.00521)\end{array}$ & $\begin{array}{l}0.00116 \\
(0.00104)\end{array}$ \\
\hline $55 \leqslant$ Age $<65$ & $\begin{array}{r}0.0170^{* * *} \\
(0.00425)\end{array}$ & $\begin{array}{r}0.0138 * * * \\
(0.00255)\end{array}$ & $\begin{array}{r}0.0156 * * * \\
(0.00536)\end{array}$ & $\begin{array}{c}0.0413^{* * *} \\
(0.0119)\end{array}$ & $\begin{array}{l}0.0225 * * * \\
(0.00590)\end{array}$ & $\begin{array}{l}0.00514^{* *} \\
(0.00256)\end{array}$ \\
\hline Age $\geqslant 65$ & $\begin{array}{l}0.00801 \\
(0.00565)\end{array}$ & $\begin{array}{r}0.0109 * * * \\
(0.00321)\end{array}$ & $\begin{array}{r}0.0188 * * * \\
(0.00624)\end{array}$ & $\begin{array}{c}0.0559 * * * \\
(0.0170)\end{array}$ & $\begin{array}{l}0.0160 * * \\
(0.00735)\end{array}$ & $\begin{array}{l}0.00200 \\
(0.00267)\end{array}$ \\
\hline Year fixed effects & Yes & Yes & Yes & Yes & Yes & Yes \\
\hline Observations & 5,527 & 12,207 & 3,452 & 3,455 & 6,876 & 2,397 \\
\hline Positive observations & 1,526 & 4,087 & 3,452 & 1,622 & 2,915 & 73 \\
\hline
\end{tabular}

Robust SE in parentheses.

$* * * \mathrm{p}<0.01, * * \mathrm{p}<0.05, * \mathrm{p}<0.1$.

Note: Marginal Effect estimates. Dependent variable is the ratio of contributions to pre-interest business income. (1)-(5) are same as in column (5) of Table 3 , but (1) excludes married individuals; (2) excludes observations with contributions above the maximum DC limit (max ratio of 0.25 ); (3) same as (2) but also excludes observations with contributions below the IRA limits; (4) is limited to observations where capital income exceeds interest expenses; (5) is limited to observations where capital income is less than interest expenses, and (6) is limited to observations where debt expenses $=$ capital income $=0$. 
consistent with the figures reported at the bottom of Table 2, and highlights the importance of having the group of large contributors in the sample.

Column (3) further removes observations with contributions below the IRA limit, $\$ 2,000$ or $\$ 5,000$ depending on year, for the subsample in column (2). The sample is thus limited to observations with positive contributions in excess of the IRA limits but below the DC limit; the observed minimum contribution to income ratio in the subsample is about 0.001 and rises to a high of close to 0.25 . The Tobit IV estimates show that the marginal effect of business debt is now larger, in absolute value, where as that of household debt is no longer significant. The marginal effect of capital income remains unchanged. In contrast, the marginal effect of business income switches signs and the marginal effect of the tax price increases in size, in absolute value. The latter should not be surprising given that the sample is now restricted to contributors only who are better off individuals as suggested by the first row of Table 2, which is likely hindering the identification of the tax rate effects.

As a further robustness test, the sample is split into three groups; those who report more capital income than interest expenses, those who report more in interest expenses than capital income, and those with equal debt and capital income flows (equal to zero). ${ }^{19}$ Estimates for the first group, which is unlikely to be liquidity constrained, are reported in column (4) of Table 5. The marginal effect on business debt retains its negative sign and significant value whereas the marginal effect on housing debt is not precisely measured. The marginal effect on capital income is now much larger than the estimate reported earlier, in contrast to that of business income which is no longer significant. The marginal effect of the tax price is much larger, in absolute value.

Moving to group two, where interest expenses exceed capital income, and who are more likely to be liquidity constrained, the earlier qualitative results for business and housing debts are retained. The marginal effect on business debt is once again negative whereas the marginal effect of housing debt is positive. Similarly the marginal effect on capital income retains its earlier value and significance. In contrast, the marginal effect on business income is no longer significant, whereas the marginal effect on the tax price retains its earlier value and sign.

The third group, where capital income is exactly equal to interest expenses and equal to zero, consists of 2,344 observations. Of these, only 73 observations, or some $3 \%$ of the sample, reported positive contributions. Because debts and capital income do not exist, estimates comparable with those obtained earlier cannot be generated. Given the small number of contributors, meaningful estimates are unlikely to be obtained. Indeed, and as reported in column (6), the marginal effect on business income is not precisely measured, whereas the marginal effect of the net of tax rate has the wrong sign (positive). ${ }^{20}$

19 Two observations for the third group are excluded where income and debt expenses are equal, but are greater than zero.

20 In one additional robustness test not reported, observations of potentially part time self-employed are dropped. Hours of work necessary to identify such individuals are not observed in tax records. As an alternative, observations with business income under $\$ 10,000$ are excluded. The estimated marginal 


\section{Concluding remarks}

This paper explored the retirement arrangements of the self-employed and the factors that influence participation and contributions a decade ago. The general findings on the effects of income and taxes on contributions are very much in harmony with previous studies. A novel finding is the dichotomy in the estimated effects of business interest expenses and that of mortgage interest expenses. The estimated negative marginal effects of business debts are robust to a number of specifications. In contrast, the marginal effects of housing debt are positive, and seems to matter the most when the individual is liquidity constrained.

While providing a snapshot of the behavior of the self-employed, the findings on the tax treatment of debt illustrate how tax provisions unrelated to tax incentives to save for retirement interact in ways unintended by legislatures and policy makers. As an example, the self-employed seem to rely on the mortgage interest deduction as a way to fund retirement savings. In the absence of this deduction, it is very likely that contributions to retirement plans may decline as mortgages are paid down.

\section{References}

Amromin, G., Huang, J., and Sialm, C. (2007) The tradeoff between mortgage prepayments and tax-deferred retirement savings. Journal of Public Economics, 91(10): 2014-2040.

Benjamin, D. J. (2003) Does 401(k) eligibility increase saving? Evidence from propensity score subclassification. Journal of Public Economics, 87: 1259-1290.

Bernanke, B. S., Gertler, M., and Gilchrist, S. (1999) The financial accelerator in a quantitative business cycle framework. In Taylor, J. B. and Woodford, M. (eds), Handbook of Macroeconomics, 1st ed., Volume 1. Amsterdam: Elsevier, pp. 1341-1393.

Chetty, R., Friedman, J., Leth-Petersen, S., Nielsen, T., and Olsen, T. (2014) Active vs. passive decisions and crowd-out in retirement savings accounts: evidence from Denmark. Quarterly Journal of Economics, 129(3): 1141-1219.

Engen, E., Gale, W. G., and Scholz, J. K. (1996) The illusory effects of saving incentives on saving. Journal of Economic Perspectives, 10(4): 113-138.

Engen, E. M. and Gale, W. G. (2000) The effects of 401(k) plans on household wealth: Differences across earnings groups. National Bureau of Economic Research Working Paper 8032, Cambridge, MA.

Evans, D. S. and Jovanovic, B. (1989) An estimated model of entrepreneurial choice under liquidity constraints. Journal of Political Economy, 97(4): 808-827.

Fazzari, S. M., Petersen, B. C., and Hubbard, R. G. (1988) Financing constraints and corporate investment. Brookings Papers on Economic Activity, 1: 141-195.

Feenberg, D. (1987) Are tax price models really identified: The case of charitable giving. National Tax Journal, 40(4): 629-633.

Feenberg, D. R. and Skinner, J. (1989) Sources of IRA saving. In L. H. Summers (ed), Tax Policy and the Economy, Volume 3. Cambridge: MIT Press, pp. 25-46.

Gale, W. (1999) The Impact of Pensions and 401(k) Plans on Saving: A Critical Assessment of the State of the Literature. Paper presented at Brookings, the Stanford Institute for Economic Policy Research, and TIAA-CREF Institute Conference entitled 'ERISA after 25 Years: A Framework for Evaluating Pension Reform,' Washington, D.C. Available at http://www. brookings.edu/ES/events/erisa/99Papers/erisa4.pdf

effects of key variables previously reported in column (5) of Table 3 change little, except for that of income which becomes imprecisely measured. 
Gale, W. G. and Scholz, J. K. (1994) IRAs and household saving. American Economic Review, 84: $1233-1260$.

Heim, B. T. and Lurie, I. Z. (2012) The effect of recent tax changes on tax-preferred saving behavior. National Tax Journal, 65(2): 283-311.

Holtz Eakin, D., Joulfaian, D., and Rosen, H. (1994) Sticking it out: Entrepreneurial survival and liquidity constraints. Journal of Political Economy, 102(1): 53-75.

Hubbard, G. and Gentry, W. (2004) Entrepreneurship and Household Saving. Advances in Economic Analysis and Policy, 4(1): 1-55.

Hubbard, R. G. and Skinner, J.S. (1996) Assessing the effectiveness of saving incentives. Journal of Economic Perspectives, 10(4): 73-90.

Joulfaian, D. (2009). Retirement arrangements of the self-employed, mimeo, http://papers.ssrn. com/sol3/papers.cfm?abstract_id=1488418.

Joulfaian, D. and Richardson, D. (2001) Who takes advantage of tax-deferred saving programs? Evidence from federal income tax data. National Tax Journal 54(3), 669-688.

Kotlikoff, L. J. (1990) The crisis in US saving and proposals to address the crisis. National Tax Journal 43, 233-246.

Kusko, A., Poterba, J. M., and Wilcox, D. W. (1994) Employee Decisions With Respect to 401 (k) Plans: Evidence from Individual Level Data. NBER Working Paper No. 4635, Cambridge, MA: National Bureau of Economic Research.

Lundberg, S. J. and Pollak, R. A. (1996) Bargaining and distribution in marriage. Journal of Economic Perspectives 10(4): 139-158.

Manchester, J. and Poterba, J. (1989) Second mortgages and household saving. Journal of Regional Science and Urban Economics 19(2): 325-346.

Poterba, J. M., Venti, S. F., and Wise, D. A. (1995) Do 401(k) contributions crowd out other personal saving? Journal of Public Economics 58(1): 1-32.

Poterba, J. M., Venti, S. F., and Wise, D. A. (1996) How retirement saving programs increase savings. Journal of Economic Perspectives, 10(4): 91-112.

Power, L. and Rider, M. (2002) The effect of tax-based savings incentives on the self-employed. Journal of Public Economics, 85(1): 33-52.

Stiglitz, J. E. (1983) Some aspects of the taxation of capital gains. Journal of Public Economics 21, 257-294. 